\title{
Parasitic Contamination Of Vegetables In Three Selected Local Government Areas Of Adamawa State
}

\author{
Richard Sylvester Yale ${ }^{1}$, Micah Sale Pukuma ${ }^{1}$, Jibril Hamman Buduwara ${ }^{1}$ and Ruth Sami ${ }^{1}$ \\ ${ }^{1}$ Department of Zoology, Modibbo Adama University of Technology, Yola, Nigeria. \\ DOI: 10.29322/IJSRP.11.08.2021.p11632 \\ http://dx.doi.org/10.29322/IJSRP.11.08.2021.p11632
}

\begin{abstract}
Fresh vegetables are important element of human food for healthy living. Yet the use of fresh vegetables plays an important epidemiological role in the transmission of food-borne parasitic diseases. This study was conducted to identify parasitic organisms whose cysts and ova are present in vegetables, determined the prevalence of pests on vegetables and to assess the distribution and the contamination of vegetables with cyst and parasitic eggs. Three local government areas were randomly selected by balloting in Adamawa State, North-eastern, Nigeria. A total of 525 fresh vegetable samples comprising of 35 grams each of Spinach (Spinacia oleracea), Sorrel (Rumex acetate), (Allium cepa), Radish (Moringa oleifera), and Sesame (Sesamum orientale), were purchased from vegetable farms of Loko, Dasinhausa and Gerio in Song, Fufore and Yola-North Local Government Areas of Adamawa State. Sedimentation and flotation techniques were used by centrifugation at $2000 \mathrm{rpm}$ for 3 minutes, twice, to extract parasitic stages using normal saline solutions and zinc sulphate. After microscopic examination under $\mathrm{X} 40$ and X100 results indicated 14 parasites, including 6 protozoa and 8 helminths were identified of which Ascaris sp 169 (32.2\%) had the highest occurrence, followed by Entamoeba sp 146 (27.8\%) while Strongyloides sp 118 (22.5\%) was the third most occurring species whereas Enterobius $s p$ 15(2.9\%) and Toxoplasma sp 11(2.1\%) were the least occurring parasites. Spinach $87(49.7 \%)$ had the highest level of contamination, followed by sorrel $76(43.4 \%)$, sesame $46(26.3 \%)$ and onion 42 (24.0\%) and radish 24 (13.7\%). The differences between levels of contamination of individual vegetables in the study areas were statistically significant $(\mathrm{P}<0.05)$. The study showed that vegetables under study were highly contaminated by parasitic cysts and ova.
\end{abstract}

\section{INTRODUCTION}

$\mathrm{V}$ egetables are a vital part of human diet because of their nutritional value. They are rich sources of the small proportion of Proteins, Fat and high proportion of vitamins such as Vitamin A, B 6 , C and K. Several studies have reported that vegetables also contain dietary minerals like Calcium, Magnesium, Potassium, Iron and a variety of phytochemicals that have antioxidants, anti-bacterial, anti-viral and carcinogenic properties (Ada et al., 2018). Food and Agricultural Organization (FAO) and WHO (2003), recommended the intake of $400 \mathrm{~g}$ of vegetables and fruits daily for the prevention of chronic diseases such as heart diseases, cancer, diabetes and obesity as well as for the prevention and alleviation of several micronutrient deficiencies, especially in less developed countries. Several studies within and outside Nigeria have reported the presence of many protozoan cysts, helminth eggs, larvae and parasites like A. lumbricoides, T. trichiura, S. stecoralis, Fasciola spp, Hookworm, G. lambia, E. histolytica, I. belli and E. vermicularis in vegetables. Their presence is still a public health concern due to gastrointestinal infection (Simon-Oke et al., 2014; Tefera et al., 2014). Because vegetables are edible plants, whose leaves, roots, stems or succulent fruits are eaten raw or partially cooked they have a tendency to host protozoan cysts, cysts, helminth eggs and larvae. Hence, despite the significant role that vegetables play in human life, their consumption constitutes a major epidemiological means of transmission of parasitic food borne diseases. For example, the problem of gastrointestinal infection is becoming of increasing concern because of the expanding number of susceptible people, the elderly and the immune-compromised in the developing countries (Alhabal, 2015). The role of poor hygiene and sanitation in the epidemiology of parasitic disease transmission has been identified with the housefly (Musca domestica) being responsible for the transmission of intestinal parasites in Ibadan and Espuma in Nigeria (Gupta et al., 2009; Adeyeba and Okpala, 2000; Nmorsi et al., 2006). In addition, contamination could be through insects contaminated with infected feces (Istifanus and Panda, 2018) while in transportation. However, while the presence of intestinal parasites in vegetable samples is suggestive of fecal contamination (Chiodini, 2001), the conveyance of fruits and vegetables in the early hours of the morning from farms to the markets with either by motor-cycles, tri-cycles or in dirty rickety pick-up vans which sometimes are loaded with passengers is another cause of contamination indicating sociocultural practices in certain geographical areas as the main causes of different levels of contamination (Istifanus and Panda, 2018). Also, some reports from different parts of the world identified the use of untreated wastewater as a major cause of parasitic contamination on vegetables (Al- Binali et al., 2006). Consequently, owing to the diversity and universality of the problem of parasitic contamination more attention and further investigation highlighting mainly the role of foods especially vegetables in the transmission of parasitic diseases is required. Therefore, this study was conducted to determine the presence and prevalence of parasites and the extent of contamination of vegetables by parasites in the study area.

\section{MATERIALS AND METHODS}

\section{Study Area}


Three vegetable farms were selected randomly by balloting; one in each of the three Local Government Areas in Adamawa State, Nigeria. These are; Dasin- Hausa in Fufore LGA which lies on the coordinate $9^{0} 13^{\prime} \mathrm{N} 12^{0} 39^{\prime} \mathrm{E}$ with the total population of 209,460 (Wale, 2014), Gerio in Yola North LGA which lies on the coordinate $9^{0} 13$ ' $48^{\prime \prime} \mathrm{N} 12^{0} 2736$ " E with the total population of 392,854 (FRN, 2016) and Loko in Song LGA which lies on the coordinate $9^{0} 49$ " 28 " $\mathrm{N}, 12^{0} 37$ '30" E with the population of 195,188 (Aliyu and Orisakwe, 2006).

\section{Study Population}

A total of 525 samples comprising of 35 samples each of Spinach"Aleho" (Spinacia oleracea), Onion "Albasa" (Allium cepa), Sesame leaves "Karkaashii” (Sesamum orientale), Sorrel "Yakuwa" (Rumex acetosa), Horseradish tree "Zoogale" (Moringa oleifera) were purchased from different farms in the selected farms across the three Local Government Areas in the early hours of the morning between 7:00Am and 9:00Am. Collected samples were stored in sterile polythene bags and labelled accordingly before transportation for laboratory analysis at the Zoology laboratory

\section{Data Collection and Analysis}

Vegetable samples were selected randomly from the vegetable farms in each of the selected Local Government Area. The vegetable samples were purchased from the farms in the selected local government areas, placed in a sterile polythene bag and label accordingly between the hours of 7:00 a.m. to 9:00 a.m. and transported to the laboratory for analysis. Laboratory analysis was conducted at the Zoology laboratory of the Department of Zoology, Modibbo Adama University of Technology, Yola Nigeria. The samples were washed in $250 \mathrm{ml}$ of $0.9 \%$ Sodium chloride solution. Both the sedimentation (were centrifuged at $2000 \mathrm{rpm}$ in Normal saline) and simple floatation (using Zinc sulphate solution of 1.18-1.20 specific gravity) techniques was performed on each sample to isolate and identify parasites as described by Elaigwu, 2015

\section{Identification of Parasites Stages}

Identification of the cysts, and eggs of encountered parasites were done on the basis of morphological characteristics with reference to keys. (Cheesbrough, 2006).

\section{Statistical Data Analysis}

Data were analyzed using the Statistical Package for Social Sciences (SPSS) software version 22. The data were analyzed by
Chi- square test using SPSS to compare the levels of contamination of different vegetables across the study areas $(\mathrm{P}<$ $0.05)$.

\section{RESULTS}

\section{Distribution of Parasite}

A total of 14 parasites comprising of 6 protozoans namely; Entaemoeba histolytica, Cryptosporidium parvum, Cyclospora cayetanensis, Isospora belli, Giardia lamblia and Toxoplasma gondii and 8 heminths including Ascaris lumbricoides, Hymenolepsis nana, Strongyloides stercoralis, Toxocara canis, Taenia saginata, Enterobius vermicularis, Trichiuri trichiura and hookworm ere encountered (Table 4. 1)

Table 4. 2 showed, Gerio had the highest number of parasites identified with 391(45.7\%), followed by Loko $275(32.2 \%)$, and Dasin-hausa 189(22.1\%). Furthermore, out of the five vegetable samples collected for the study, Spinach $272(51.8 \%)$, had the highest number of infestation with parasites, followed by Sorrel 217(41.3\%), while Radish 60(11.4\%) had the least occurrence. There was no significant relationship between the levels of contamination $(\mathrm{P}>0.05)$.

Samples from the study areas showed parasites cysts and eggs on vegetables. Out of the 175 vegetables samples, Spinach $87(49.7 \%)$, had most frequent occurrence, followed by Sorrel $76(43.4 \%)$ while $24(13.7 \%)$ infestation was found in Radish (Table 4. 3).

Among the parasites observed on the vegetables, Ascaris lumbricoides 55(31.4\%) had the highest distribution, Entamoeba histolytica of 43(24.7\%), over Strongyloides stercoralis with $40(22.9 \%)$ and $G$. lamblia was the least of the samples from different areas. There was no significant relationship between the levels of contamination of samples from different areas $(\mathrm{P}>0.05)$. Out of a total 175 vegetable samples collected and examined in Dasin-hausa, Spinach 59(33.7\%) had the most frequent number of the parasites cysts and eggs, followed by Sorrel 41(24.4\%) and Radish had the least occurrence of 15(8.6\%) (Table 4.4). Meanwhile, Ascaris lumbricoides 48(27.4\%) had the highest distribution, followed by Entamoeba histolytica 33(18.6\%) and Strongyloides stercoralis 32(18.3\%) while $T$. trichiura was the least. There was significant relationship between the levels of contamination $(\mathrm{P}<0.05)$.

Table 4.1 Parasitic Contamination of Vegetable in 3 Selected Farms LGAs of Adamawa State, Nigeria $(\mathbf{N}=\mathbf{5 2 5})$.

\begin{tabular}{lllllll}
\hline $\begin{array}{l}\text { Parasitic } \\
\text { Contaminants }\end{array}$ & Gerio & Farms & & Total & Chi-Square & Df
\end{tabular}

\begin{tabular}{llllllll}
\hline Protozoa & & & & & & \\
G. lamblia & $3(1.7)$ & $11(6.3)$ & $2(1.1)$ & $16(3.0)$ & 8.42 & 2 & $0.368 \mathrm{~ns}$ \\
C. parvum & $22(12.6)$ & $14(8.0)$ & $17(9.7)$ & $53(10.1)$ & 13.1 & 2 & $0.368 \mathrm{~ns}$ \\
E. histolytica & $70(40)$ & $33(18.9)$ & $43(24.6)$ & $146(27.8)$ & 18.1 & 2 & $0.368 \mathrm{~ns}$ \\
\hline
\end{tabular}

This publication is licensed under Creative Commons Attribution CC BY. 


\begin{tabular}{llllllll}
\hline C. cayetanensis & $40(22.9)$ & $12(6.9)$ & $35(20)$ & $87(16.6)$ & 10.4 & 2 & $0.217 \mathrm{~ns}$ \\
$\begin{array}{l}\text { I. belli } \\
\text { T. trichiura }\end{array}$ & $16(9.1)$ & $4(2.3)$ & $14(8)$ & $34(6.5)$ & 45.67 & 2 & $0.004^{* *}$ \\
$\begin{array}{l}\text { Helminths } \\
\text { T. canis }\end{array}$ & $15(8.6)$ & $1(0.6)$ & $3(1.7)$ & $19(3.6)$ & 12.31 & 2 & $0.368 \mathrm{~ns}$ \\
A. lumbricoides & $37(21.1)$ & $0(0)$ & & & & & \\
Toxoplasma sp & $66(37.7)$ & $48(27.4)$ & $55(31.4)$ & $169(32.2)$ & 22.3 & 2 & $0.112 \mathrm{~ns}$ \\
S. stercoralis & $11(6.3)$ & $0(0)$ & $0(0)$ & $11(2.1)$ & 6.87 & 2 & $0.368 \mathrm{~ns}$ \\
Hymennolepsis sp & $46(26.3)$ & $32(18.3)$ & $40(22.9)$ & $118(22.5)$ & 23.81 & 2 & $0.122 \mathrm{~ns}$ \\
T. saginata & $18(10.3)$ & $11(6.3)$ & $6(3.4)$ & $35(6.7)$ & 23.21 & 2 & $0.101 \mathrm{~ns}$ \\
E. vermicularis & $39(22.3)$ & $6(3.4)$ & $24(13.7)$ & $69(13.1)$ & 25.59 & 2 & $0.000^{* *}$ \\
Hookworm sp & $8(4.6)$ & $0(0)$ & $7(4)$ & $15(2.9)$ & 12.54 & 2 & $0.234 \mathrm{~ns}$ \\
Total & $0(0)$ & $17(9.7)$ & $0(0)$ & $17(3.2)$ & 17.45 & 2 & $0.123 \mathrm{~ns}$ \\
\hline
\end{tabular}

Table 4. 2 Prevalence of Vegetable Contamination among 3 Selected Farms in Adamawa State, $(\mathrm{N}=525)$

\begin{tabular}{llllllllll}
\hline Farms & Spinach & Sorrel & $\begin{array}{l}\text { Vegetable } \\
\text { Onion }\end{array}$ & $\begin{array}{l}\text { type } \\
\text { Radish }\end{array}$ & Sesame leaves & Total & Chi-Square & Df & P-value \\
\hline Gerio & $126(32.2)$ & $100(25.6)$ & $69(17.6)$ & $21(5.4)$ & $75(19.2)$ & $391(45.7)$ & 42.00 & 4 & $0.046 \mathrm{~ns}$ \\
Dasin-Hausa & $59(31.2)$ & $41(21.7)$ & $32(16.9)$ & $15(7.9)$ & $42(22.2)$ & $189(22.1)$ & 14.00 & 4 & $0.442 \mathrm{~ns}$ \\
& & & & & & & & & \\
Loko & $87(31.6)$ & $76(27.6)$ & $42(15.3)$ & $24(8.7)$ & $46(16.7)$ & $275(32.2)$ & 40.00 & 4 & $0.036^{* *}$ \\
Total & $272(51.8)$ & $217(41.3)$ & $143(27.2)$ & $60(11.4)$ & $163(31)$ & $855(100)$ & 123.00 & 4 & $0.0021^{* *}$
\end{tabular}

Table 4. 3 Contamination of Different Vegetables by Parasitic Cysts and Ova in Loko Farm, Song LGA (N=175).

\begin{tabular}{llllllll}
\hline $\begin{array}{l}\text { Identified } \\
\text { Parasite }\end{array}$ & Spinach & Sorrel & $\begin{array}{l}\text { Vegetable } \\
\text { Onion }\end{array}$ & $\begin{array}{l}\text { types } \\
\text { Radish }\end{array}$ & $\begin{array}{l}\text { Sesame } \\
\text { leaves }\end{array}$
\end{tabular}

\begin{tabular}{|c|c|c|c|c|c|c|c|c|c|}
\hline \multicolumn{10}{|l|}{ Protozoa } \\
\hline G. Iamblia & $1(2.9)$ & $1(2.9)$ & $0(0)$ & $0(0)$ & $0(0)$ & $2(1.1)$ & 3.65 & 4 & $0.406 \mathrm{~ns}$ \\
\hline C. parvum & $6(17.1)$ & $7(20)$ & $3(8.6)$ & $1(2.9)$ & $0(0)$ & $17(9.7)$ & 4.67 & 4 & $0.406 \mathrm{~ns}$ \\
\hline E. histolytica & $13(37.1)$ & $10(28.6)$ & $6(17.1)$ & $3(8.6)$ & $11(31.4)$ & $43(24.7)$ & 20.67 & 4 & $0.023^{* *}$ \\
\hline C. cayetanensis & $11(31.4)$ & $10(28.6)$ & $3(8.6)$ & $7(20)$ & $4(11.4)$ & $35(20)$ & 21.99 & 4 & $0.033 * *$ \\
\hline Toxoplasma spp & - & - & - & - & - & - & - & - & - \\
\hline \multicolumn{9}{|l|}{ Helminths } & $0.406 n s$ \\
\hline S. stercoralis & $10(28.6)$ & 10(28.6) & $9(25.7)$ & $7(20)$ & $4(11.4)$ & $40(22.9)$ & 19.45 & 4 & $0.223 \mathrm{~ns}$ \\
\hline T. trichiura & $1(2.9)$ & $0(0)$ & $0(0)$ & $0(0)$ & $2(5.7)$ & $3(1.7)$ & 2.70 & 4 & $0.406 \mathrm{~ns}$ \\
\hline T. canis & $8(22.9)$ & $12(34.3)$ & $3(8.6)$ & $1(2.9)$ & $5(14.3)$ & $29(16.6)$ & 12.8 & 4 & $0.076 \mathrm{~ns}$ \\
\hline Hymennolepsis spp & $3(8.6)$ & $1(2.9)$ & $0(0)$ & $0(0)$ & $2(5.7)$ & $6(3.4)$ & 1.23 & 4 & $0.406 \mathrm{~ns}$ \\
\hline A. lumbricoides & 17(48.6) & $12(34.3)$ & $9(25.7)$ & $4(11.4)$ & 13(37.1) & $55(31.4)$ & 23.87 & 4 & $0.002 * *$ \\
\hline T. saginata & $9(25.7)$ & $7(20)$ & $5(14.3)$ & $0(0)$ & $3(8.6)$ & $24(13.7)$ & 11.45 & 4 & $0.243 \mathrm{~ns}$ \\
\hline E. vermicularis & $3(8.6)$ & $4(11.4)$ & $0(0)$ & $0(0)$ & $0(0)$ & $7(4)$ & 3.78 & 4 & $0.406 \mathrm{~ns}$ \\
\hline Total & $87(49.7)$ & $76(43.4)$ & $42(24)$ & $24(13.7)$ & $46(26.3)$ & $275(100)$ & 234.87 & 4 & $0.00031^{* *}$ \\
\hline
\end{tabular}




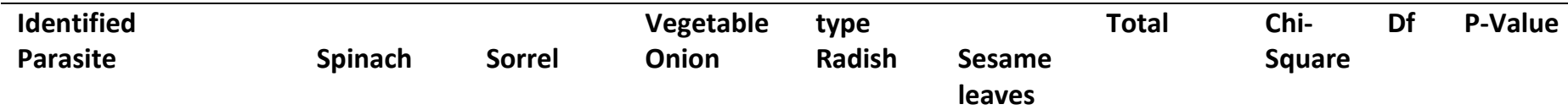

Protozoa

$\begin{array}{llllllllll}\text { I. belli } & 7(20) & 0(0) & 6(17.1) & 0(0) & 3(8.6) & 16(9.1) & 4.00 & 4 & 0.406 \mathrm{~ns} \\ \text { C. parvum } & 8(22.9) & 9(25.7) & 4(11.4) & 0(0) & 1(2.9) & 22(12.6) & 12.65 & 4 & 0.021^{* *} \\ \text { E. histolytica } & 19(54.3) & 16(45.7) & 14(40) & 4(11.4) & 17(48.6) & 70(40) & 32.67 & 4 & 0.002^{* *} \\ \text { Cyclospora spp } & 13(37.1) & 11(45.7) & 8(22.9) & 3(8.6) & 5(14.3) & 40(22.9) & 12.95 & 4 & 0.342 \mathrm{~ns} \\ \text { G. lamblia } & 2(5.7) & 1(2.9) & 0(0) & 0(0) & 0(0) & 3(1.7) & 4.00 & 4 & 0.406 \mathrm{~ns}\end{array}$

Helminths

T. gondii

A. lumbricoides

Hymennolepsis spp

1(2.9) $\quad 3(8.6)$

22(62.9) $14(40)$

$5(14.3) \quad 0(0)$

13(37.1)

2(5.7)

2(5.7)

$5(14.3) \quad 4(11.4)$

$0(0)$

$0(0)$

15(42.9)

11(6.3)

4.00

4

$0.406 \mathrm{~ns}$

T. canis

11(31.4)

14(40)

0(0)

9(25.7)

66(37.7)

$43.76 \quad 4$

$0.032 * *$

S. stercoralis

14(40)

12(34.3)

5(14.3)

$7(20)$

18(10.3)

$4.00 \quad 4$

0.406 ns

T. trichiura

8(22.9)

4(11.4)

11(31.4)

2(5.7)

$37(21.1)$

$13.77 \quad 4$

0.221 ns

T. saginata

11(31.4)

9(25.7)

$0(0)$

$7(20)$

46(26.3)

$13.67 \quad 4$

$0.221 \mathrm{~ns}$

E. vermicularis

5(14.3)

3(8.6)

8(22.9)

$0(0) \quad 3(8.6)$

15(8.6)

4.00

0.406 ns

Total

126(32.2)

100(25.6)

$0(0)$

5(14.3)

6(17.1)

39(22.5)

14.23

$0.021 * *$

69(17.6)

0(0) 0(0)

8(4.6)

4.00

$0.406 \mathrm{~ns}$

$391(45.7) \quad 123.22 \quad 4 \quad 0.00010^{* *}$

Table 4. 4 Cysts and Eggs of Parasitic Organisms on consumed vegetables in Dasin-Hausa Farm, Fufore LGA (N=175).

\begin{tabular}{|c|c|c|c|c|c|c|c|c|c|}
\hline Identified & & & Vegetables & types & & Total & Chi- & Df & P-Value \\
\hline Parasite & Spinach & Sorrel & Onion & Radish & $\begin{array}{l}\text { Sesame } \\
\text { leaves }\end{array}$ & & Square & & \\
\hline
\end{tabular}

\begin{tabular}{|c|c|c|c|c|c|c|c|c|c|}
\hline \multicolumn{10}{|l|}{ Protozoa } \\
\hline I. belli & $3(8.6)$ & $0(0)$ & $1(2.9)$ & $0(0)$ & $0(0)$ & $4(2.3)$ & 4.00 & 4 & $0.406 n s$ \\
\hline C. parvum & $6(17.1)$ & $4(11.4)$ & $0(0)$ & $0(0)$ & $4(11.4)$ & $14(8)$ & 12.12 & 4 & $0.012 * *$ \\
\hline E. histolytica & 11(31.4) & $7(20)$ & $1(2.9)$ & $8(22.9)$ & $6(17.1)$ & $33(18.6)$ & 14.66 & 4 & $0.021 * *$ \\
\hline C. cayetanensis & $0(0)$ & $2(5.7)$ & $9(25.7)$ & $1(2.9)$ & $0(0)$ & $12(6.9)$ & 13.55 & 4 & $0.003 * *$ \\
\hline G. lamblia & $1(2.9)$ & $1(2.9)$ & $6(17.1)$ & $0(0)$ & $3(8.6)$ & $11(6.3)$ & 4.00 & 4 & $0.406 * *$ \\
\hline \multicolumn{10}{|l|}{ Helminths } \\
\hline Hymennolepsis spp & $0(0)$ & $3(8.6)$ & $0(0)$ & $1(2.9)$ & $7(20)$ & $11(6.3)$ & 4.00 & 4 & $0.406 n s$ \\
\hline A. lumbricoides & $15(42.9)$ & $13(37.1)$ & $10(28.6)$ & $1(2.9)$ & $9(25.7)$ & $48(27.4)$ & 23.56 & 4 & $0.002 * *$ \\
\hline S. stercoralis & $11(31.4)$ & $7(20)$ & $3(8.6)$ & $3(8.5)$ & $8(22.9)$ & $32(18.3)$ & 21.36 & 4 & $0.011 * *$ \\
\hline T. trichiura & $0(0)$ & $0(0)$ & $0(0)$ & $0(0)$ & $1(2.9)$ & $1(0.6)$ & 4.00 & 4 & $0.406 * *$ \\
\hline T. saginata & $5(14.3)$ & $0(0)$ & $0(0)$ & $0(0)$ & $1(2.9)$ & $6(3.4)$ & 4.00 & 4 & $0.406 * *$ \\
\hline Hookworm spp & $7(20)$ & $4(11.4)$ & $2(5.7)$ & $1(2.9)$ & $3(8.6)$ & $17(9.7)$ & 14.23 & 4 & $0.052 \mathrm{~ns}$ \\
\hline Total & 59(33.7) & $41(23.4)$ & $32(18.3)$ & $15(8.6)$ & $42(24)$ & 189(36) & 76.98 & 4 & $0.00011 * *$ \\
\hline
\end{tabular}

Table 4. 5 showed the distribution of parasite cysts and eggs on different vegetables in Gerio farm. Spinach were more contaminated with parasitic cyst and eggs with 126(32.2\%), Sorrel 100(25.6\%), while Radish 21(5.4\%) was the least infested vegetable. According to this study, Entamoeba histolytica were more frequent with 70(40\%), Ascaris lumbricoides 66(37.7\%), Strongyloides stercoralis 46(26.3\%). Giardia lamblia was the least most frequent parasite as shown above. There was significant relationship between the levels of contamination $(\mathrm{P}<0.05)$.

Table 4.5 Contamination of Different Vegetables with Cysts and Eggs of Parasites in Gerio Farm, Yola North LGA (N=175).

\section{DISCUSSION}

The levels of prevalence of parasitic agents on vegetables in this present study were lower than in similar reports in Iran 32\% (Daryani et al., 2008) and India 44\% (Gupta et al., 2009). Sorrel
$217(25.4 \%)$ had the second level of infestation of parasites cysts and eggs. This could be due to the broad and large surface area of the leaves which are in close proximity with the sewage contaminated soil surface (Larkin et al., 1978). Sesame 163 (19.0\%) had a contamination level next to sorrel in line with the 
findings of Maikai et al (2012). Although the leaves of Sesame are not broad and have a small surface area, the large number of the leaves on the stalk could be the reason for this level of occurrence of cysts and eggs of parasites on the vegetable. Onion $143(16.7 \%)$ was among the least contaminated vegetables with cysts and eggs of parasites. This agrees with the study of Uga et al (2009), which showed that contamination is usually higher in the leafy than the root and fruity vegetables. Radish 60 (7.0\%) had the least contamination with cysts and eggs of the various parasitic organisms due perhaps to the shape and surface of the vegetables (El-Said, 2012). The overall prevalence of cysts and eggs of the different parasites identified on vegetables in the study areas differed. This largest occurrence was at Gerio, 391 (45.7\%), followed by Loko 275 (32.2\%) and Dasin-hausa $189(22.1 \%)$. This difference in contamination levels among study areas could be attributed to varying environmental conditions and other hygiene factors ranging from indiscriminate open defecation habits on farm soils by children and adults, use of animal dungs as organic manure, poor personal and domestic hygiene, the kind of water used for irrigation as well as methods of transportation which constitutes favorable conditions for transmission unto vegetables (Pires et al., 2012: Auta et al., 2017). Among the parasites screened on various vegetables in the study areas, A. lumbricoides was more predominant. This finding is similar to those of (Uneke, 2007; Istifanus and Panda, 2018; Gupta et al., 2009; and Shafa-ulHaq et al., 2014) in Nigeria, India and Pakistan respectively. This seems to be due to the epidemiological factors that cause the spread of pests, especially in poor health conditions and practices, poor housing and high population density, and illiteracy in the developing world. The relatively high occurrence of Ascaris spp and Strongyloides spp reported in this study agrees with Fagbero et al. (2016). However, detection of some parasites such as Ascaris lumbricoides, Ancylostoma, Strongyloides and Giardia in our samples suggests poor hygienic standard in the study areas. The parasites screened have mainly fecal origin implying fecal contamination of the samples. This kind of contamination is increased by poor sanitary conditions and hygienic habits (Damen et al., 2007; Daryani et al., 2008; Slifko et al., 2000). Thus, intestinal parasitic infections are expected in the area where there is low standard of personal hygiene as well as poor sanitary conditions. In this study, of the parasites detected, Ascaris $s p$ was the most frequently detected, followed by Entamoeba $s p$, Strongyloides sp, Cyclospora sp, Taenia sp and Toxocara sp. This report is in contrast to the study of (Al- Kassr, 2010) which reported that Entamoeba $s p$ had the most detected parasites followed by Entamoeba $s p$, but it was similarly reported in the case Strongyloides $s p$ and Taenia $s p$ which were the fourth and fifth according to the degrees of contamination of vegetables. The result of Table 4. 5 reported a similar result with (Al- Kassr, 2010) who studied the prevalence of different parasitic stages on commercial vegetables in Al-Nassriah City, Iran and found the highest contamination of Entamoeba $s p$, Ascaris $s p$ was reported as the second most prevalent parasitic stage. This report is also similar to the previous study in Jimma town, Ethiopia by (Girmaye and Bent, 2014) who reported Ascaris sp as the second most prevalent $(13 \%)$ of the vegetables studied in Casablanca, Morocco, but in a higher percentage in this present report $66(37.7 \%)$. Entamoeba sp was reported as the third most prevalent $(16 \%)$ which is lower than the level of contamination discovered in this study $70(40 \%)$. Similar results were obtained in Southwestern Saudi Arabia (Al- Binali et al., 2006). Although Entamoeba $s p$ a commercial intestinal parasite, its presence in high level in the sampled vegetables indicates the presence of high prevalence of contamination of the pathogenic intestinal and protozoan parasites in the study areas. This results are in agreement with (Ishaku and Ishakeku, 2013) who reported $(1.33 \%),(0.33 \%)$ and $(0.33 \%)$ for the three species respectively, with the least prevalence of Taenia and Trichiuri species, while, Taenia $s p$ was the fifth most prevalence parasite 69(13.15\%). Hookworm sp 17(3.2\%) occurred in only one study area. This disagrees with the reports of Ayaji and Agahlu (2016) and Ojemudia (2011), who reported Hookworm sp as the most prevalent helminths and the report of whose report revealed Hookworm $s p$ as the most prevalent parasite.

\section{CONCLUSION}

This study found that vegetables consumed in study areas, were contaminated with cysts and eggs from parasitic organisms. The occurrence and prevalence of the infection varies among the vegetables under study and among the areas where the vegetables were grown. Overall infection with cysts and eggs from parasitic organisms were widely distributed in the vegetables and the areas where they were grown. With market gardeners, sellers and consumers completely unaware that vegetables can carry and transmit parasites, the risk of infection amongst the human population is high. This has consequences for the overall wellbeing of the people living in these areas and are consuming vegetables produced in these areas.

\section{RECOMMENDATIONS}

i. There is a need for further research to isolate other microbes that harbours the edible vegetable.

ii. There is need to make further research on edible vegetables during wet and rainy season.

iii. The vegetable farmers, seller and consumers to wash the vegetables properly with iodized salt.

\section{REFERENCES}

[1] Ada, R. T., Obadiah, H. I., Akuma, N., Odaudu, E. and Omudu, E. A. (2018) Detection of Parasite Ova and Egg in Commonly Consumed Vegetables in Makurdi, Benue State, Nigeria. Nigerian Journal of Parasitology, 39(1):7983.

[2] Adeyeba, O. A. and Okpala, N. (2000). Intestinal Parasites and Bacterial Pathogens Carried by Common Filth Houseflies in Ibadan, Nigeria. African Journal of Medicinal and Pharmaceutical Science. 4:53-63.

[3] Al- Kassar, N. R. (2010). Prevalence of Different Parasitic Stages in Commercial Vegetables in Al- Nassiriyah City, Iraq. Pg 17-19

[4] Al-Binali, A. M., Bello, C. S., El-Shewy, K. and Abdulla, E. S. (2006). The Prevalence of Parasites in Commonly Used Leafy Vegetables in SouthWestern, Saudi Arabia Medical Journal, 27:613-616.

[5] Alhabbal, A. T. (2015). The Prevalence of Parasitic Contamination on Commonly Vegetables in Alqalamoun Region. International Journal of Pharmaceutical Science Rev. Res, 30(1): 94-97.

[6] Aliyu A. and Orisakwe K. U (2006). Aftermath of 1989 Loko Fload Disaster in Adamawa State of Nigeria. Unpublished (Master Thesis) in Land Administration, Bayero University, Kano, Nigeria. Pg 37 
[7] Auta, T., Bawa, J. A. and Suchet, C. M. (2017). Parasitic Contamination of Common Fresh Fruits and Vegetables Sold in Markets Within Dutsin- Ma Town, Katsina State, Nigeria. Journal of Advances in Biology and Biotechnology. 14: 1-8.

[8] Ayaji, F. O. and Agahiu, E. E. (2016). Contamination of Helminthes Parasites on Fruits Sold in Anyigba, Kogi State, Nigeria. Scholarly Journal of Agricultural Science. 6(6): 195-199.

[9] Cheesbrough, M. (2006). District Medical Laboratory Practice in Tropical Countries. 2nd Edition. Cambridge University Press, UK. 35 - 39

[10] Chiodini, P. L. (2001). Chemotherapy for Patients with Multiple Parasites Infection, Parasitology, 22: 583-590.

[11] Damen, JG., Banwat, E. B., Egah, D. Z. and Allanana, J. A. (2007). Parasitic Contamination of Vegetable in Jos, Plateau, State, Nigeria. Annals of African Medical Journal, 6(3): 115-118.

[12] Daryani, A., Ettehad, G. H. Sharif, M., Ghorbani, L. and Ziaei, H. (2008). Prevalence of Intestinal Parasites on Vegetables Consumed in Ardabil, Iran. Food Control. 19: 790- 794.

[13] El-Said, S. (2012). Detection of Parasite in Commonly Consumed Raw Vegetables. Alexandria Journal of Medicine, 46(2): 282-288.

[14] El-Said, S and Doaa, S. (2012). Detection of Parasites in Commonly Consumed Raw Vegetables. Alexandria Journal of Medicine, 48(4): 345-352.

[15] Elaigwu, M. A. (2015). Occurrence of Parasites Cysts and Eggs on Bank Facilities in Benue State, Nigeria. (Masters Thesis) in Educational Biology, Ahmadu Bello University, Zaria, Nigeria. Pg 89

[16] Fagbenro MT, Mogaji HO, Oluwole AS, Adeniran AA, Alabi OM, Ekpo UF (2016). Prevalence of Parasites Found in Vegetables and Perception of Retailers and Consumers about Contamination in Abeokuta Area of Ogun State, Nigeria. Journal of Clinical Microbiology and Case Reports, 2(1): 1-5

[17] Federal Republic of Nigeria (2006). Population Census (PDF). Web.archive.org from the original (PDF) on 5 March, 2012. Retrieved 15 May, 2019. Pg 3

[18] Girmaye, and Benti (2014). Parasitic Contamination on Vegetables Irrigated with Awash River in Selected Farms. Journal Parasitology Vector Biology 6:103-109.

[19] Gupta, N., Khan, D. K. and Santra, S. C. (2009). Prevalence of Intestinal Helminths Eggs on Vegetables Grown in Wastewater- Irrigated Areas of Titagarhi,West-Bengal, India Food Control, 20: 942-945.

[20] Ishaku, A., Ishakeku, D. and Agwale, S. (2013). Prevalence of Parasite Contamination of Some Edible Vegetables Sold at Alhamis Market in Lafia Metropolis. Scholarly Journal of Biotechnology, 2(2): 26-29.

[21] Istifanus, W. A. and Panda, S. M. (2018). Parasitic Agents in Fresh Fruits and Vegetables Sold in Open Markets in Bauchi, Nigeria. Journal of Food Quality and Hazards Control. 5: 84-88.

[22] Larkin, E. P, Tieney, J.T., Lovett, J., Van-Donsel, D., Francis, D. and Jackson, G. J. (1978). Land Application of Sewage Waste: Potential for Contamination of Foodstuffs and Agricultural Soils by Viruses, Bacterial Pathogens and Parasites. In: State of Knowledge in Land Treatment of Wastewater (HL Mc Kim. editor), International Symposium August 20-25, Hanover, NH: US Army Corps of Engineers. Pp 215-223

[23] Maikai, B. V., Elisha, I. A.and Baba-Onoja, F. B. T. (2012). Contamination of Vegetables Sold in Markets with Helminth Eggs in Zaria Metropolis, Kaduna State, Nigeria. Food Control, 28(2): 345-348.
[24] Nmorsi, O. P. G., Ukwandu, N. C. D. and Agbozele, G. E. (2006). Detection of Some Gastrointestinal Parasites from Four Synanthropic Flies in Espuma, Nigeria. Journal of Vector Borne Diseases. 43: 136-139.

[25] Ojemuidia, T. I. (2011). Parasitic Contamination of Fresh Vegetables Sold in Jos Markets. Global Journal Medical Research, 11: 21-25.

[26] Pires, S. M. (2012). Attributing Human Foodborne Illness to Food Sources and Water in Latin America and the Carribean Using Data from Outbreak Investigations. International Journal of Food Microbiology, 152: 129-138.

[27] Shafa-ul-Haq, S., Maqbool, A., Javed, K. U., Yasmin, G. and Sultana, R (2014). Parasitic Contamination of Vegetables Eaten Raw in Lahore, Pakistan. Pakistan Journal of Zoology. 46: 130-135.

[28] Simon-Oke, O. A., Luka, S. A. and Adebote, D. A. (2014). Evaluation of Bovine and Caprine Hepatica Parasitoses in Slaughter Houses Within Kaduna Metropolis, Nigeria. Paper Presented at the 9th Annual Conference of Zoological Society of Nigeria, University of Ibadan, Ibadan, Nigeria. Pg 4

[29] Slifko, T. R., Smith, H. W. and Rose, J. B. (2000). Emerging Parasites Zoonoses Associated With Water and Food. International Journal of Parasitology, 30: 1379-1393.

[30] Tefera, T., Biruksew, A., Mekonnen, Z. and Eshetu, T. (2014). Parasitic Contamination of Fruits and Vegetables Collected from Selected Local Markets of Jimma Town, South-West Ethiopia. International Scholarly Research Notices. 1-8

[31] Uga, S., Nagnaen, W. and Chongsuvivatwong, V. (2009 Wale, O. (2014) Aftermath of Boko Haram attacks: Victims Build New Town in Adamawa State. Daily Post Nigeria.

[32] Uneke, C. J. (2007). Potential for Parasites and Bacteria Transmission by Currency in Nigeria. Journal of Environmental Health. 69(9): 54-60.

[33] Wale, O. (2014). Aftermath of Boko Haram attacks: Victims Build New Town in Adamawa State. Daily Post Nigeria. Pg 34-36

[34] WHO. (2003). Diet, Nutrition and the Prevention of Chronic Diseases. Report of a Joint FAO/ WHO Expert Consultation. Geneva, World Health Organization Technical Report Series. No. 916

\section{AUTHORS}

First Author - Richard Sylvester Yale, Department of Zoology, Modibbo Adama University of Technology, Yola, Nigeria.

Second Author - Micah Sale Pukuma, Department of Zoology, Modibbo Adama University of Technology, Yola, Nigeria. Third Author - Jibril Hamman Buduwara, Department of Zoology, Modibbo Adama University of Technology, Yola, Nigeria.

Fourth Author - Ruth Sami, Department of Zoology, Modibbo Adama University of Technology, Yola, Nigeria.

Corresponding author email: richardyale87@gmail.com Corresponding author phone number: 08164170007 